\title{
Synthesis, NMR and Function of an O-Phosphorylated Peptide, Comprising the RGD-Adhesion Sequence of Osteopontin
}

\author{
Elisabeth Pettersson, ${ }^{a}$ Björn Lüning, ${ }^{a}$ Henrik Mickos ${ }^{a}$ and Dick Heinegård ${ }^{b}$ \\ a Department of Organic Chemistry, Arrhenius Laboratory, Stockholm University, S-10691 Stockholm, Sweden and ${ }^{\mathrm{b}}$ Department of \\ Medical Chemistry, University of Lund
}

\begin{abstract}
Pettersson, E., Lüning, B., Mickos, H. and Heinegård, D., 1991. Synthesis, NMR and Function of an $O$-Phosphorylated Peptide, Comprising the RGD-Adhesion Sequence of Osteopontin. - Acta Chem. Scand. 45: 604-608.

The bone phosphoprotein osteopontin owes its cell adhesion property to the RGD-sequence. In order to determine whether a phosphate substituent on the serine following the RGD-sequence interferes with cell binding, we have synthesized GRGDSL along with the corresponding peptide phosphorylated on serine. The latter peptide showed significantly lower cell binding as measured by inhibition of adhesion of R1 cells to surfaces coated with BSP. GRGDSL and phosphorylated GRGDSL show NMR spectra which resemble each other more than that of GRGDSP derived from the fibronectin sequence.
\end{abstract}

Osteopontin is a prominent bone matrix protein produced by osteoblasts, but is also synthesized by other cells, e.g. the distal tubular cells in the kidney. The protein is anionic, containing stretches of aspartic acid residues. Additional charge is provided by phosphate groups on about a quarter of the serine residues. Few, if any, of the threonine residues appear to be phosphorylated. ${ }^{1}$ The protein contains an RGDS sequence. The RGD tripeptide has been shown to bind cells via integrins, representing specific receptors, at the cell surface. Accordingly it has been shown that osteopontin binds cells and that this binding depends on the RGD-sequence. ${ }^{2}$

It is of interest that the protein also binds tightly to the mineral phase of the bone i.e. the hydroxylapatite, possibly at least in part a consequence of its content of phosphorylated serine residues.

Bone resorption depends on the activity of the osteoclast cells, which bind to the surface of the mineral phase of bone and locally degrade the mineralized bone. It appears that one function of osteopontin is to mediate this binding of the osteoclast. The protein is localized, much enriched, in the contact zone and the corresponding integrin, i.e. the vitronectin receptor, is found selectively at the corresponding location along the plasma membrane. ${ }^{3}$

The protein appears to be variously substituted with phosphate and carbohydrate. For instance it migrates as a rather broad diffuse band upon electrophoresis. It is not known whether differently substituted osteopontin forms have different functional properties. The presence of a serine residue following the cell binding sequence could imply a site that, when phosphorylated, alters the function of the protein, perhaps precluding or enhancing cell binding. This phosphate group could be removed by phosphatases produced by several of the bone cells and thus altering the function of the protein. The present work was performed to demonstrate whether the cell binding capacity of osteopontin is altered if the serine residue following the cell binding sequence is phosphorylated.

Several methods for the synthesis of $O$-phosphorylated peptides have been devised. However, none of the methods are generally useful and part of the published information is contradictory, indicating that optimal conditions have not yet been found for the reliable synthesis of phosphopeptides. Earlier methods used chemical ${ }^{4,5}$ and enzymatic ${ }^{6.7}$ phosphorylation of separately prepared peptides and proteins. Chemical phosphorylation of the peptides is difficult when they are synthesized with protective groups on selected hydroxy groups that can be removed before phosphorylation without harming the other protective groups. Enzymatic phosphorylation, on the other hand, is restricted to those sites which are phosphorylated in native proteins. ${ }^{7}$ A problem common to the two methods, is the difficulty of obtaining a high yield of phosphorylation at any given site.

Recent methods employ pre-synthesized $O$-phosphorylated hydroxyamino acids with appropriate protective groups which are included in solution ${ }^{8}$ or solid-phase ${ }^{9}$ peptide synthesis. Phosphate esters are fairly stable to acid and can thus be used in a Boc protocol. ${ }^{8}$ During peptide synthesis the strongly polar phosphate group has to be introduced in the form of a triester. For serine, the diphenyl ester has proved to be most suitable, since the phenyl groups can be removed after peptide synthesis by hydrogenolysis over platinum.

\section{Materials and methods}

Throughout this paper the one letter code for amino acids is used (for phosphoserine and phosphothreonine the symbols $\mathrm{S}(\mathrm{P})$ and $\mathrm{T}(\mathrm{P})$ are used). 
Peptides were synthesized manually using Merrifield's solid-phase technique with $t$-butyloxycarbonyl (Boc)-protected amino acids. ${ }^{10}$ The first Boc-amino acid was covalently linked to a Biorad ${ }^{\circledR}$ chloromethylated polystyrene resin (1.25 mequiv. $\mathrm{g}^{-1}$ substitution) according to the $\mathrm{KF}$ method $^{11}$ in DMF. Boc-serine and Boc-aspartic acid were further protected as $O$-benzyl ethers, and the guanidyl group of Boc-arginine was sulfonated with mesitylenesulfonic acid. Coupling of the Boc-amino acids to the $\mathrm{N}$-terminus of the growing peptide was effected with preformed symmetric anhydrides $\left(\mathrm{CH}_{2} \mathrm{Cl}_{2}\right)$ using diisopropylcarbodiimide (DIPCDI) as an activator with DMF as the coupling solvent. Boc-glycine and Boc-arginine were coupled as active esters in the presence of 1-hydroxybenzotriazole (HOBT) with $\mathrm{CH}_{2} \mathrm{Cl}_{2} / \mathrm{DMF} 1: 1$ as the coupling solvent, neat DMF for arginine. The coupling reaction was monitored for completion by means of the ninhydrin test. ${ }^{12}$ The complete peptide was deprotected and cleaved from the resin with Low-High HF. ${ }^{13}$ The phosphorylated peptide was synthesized using the same method, except that $10 \%$ trifluoromethanesulfonic acid in trifluoroacetic acid was used for deprotection. Boc-diphenylphosphonoserine, synthesized from diphenyl phosphochloridite and Boc-serine by the one-pot method, ${ }^{14}$ was used.

Final deprotection of the phenyl groups from the phosphate moiety was performed by hydrogenolysis in the presence of Adams' catalyst ${ }^{8}$ (1.1 mequiv. per phenyl), solvent $40 \%$ TFA in acetic acid at atmospheric pressure overnight. The peptide was precipitated from the acid with ether at $-70^{\circ} \mathrm{C}$, taken up in $10 \%$ aqueous acetic acid and lyophilized.

The non-phosphorylated peptide was desalted on Sephadex ${ }^{\circledR}$ G15 in ammonium hydrogencarbonate. Analysis and further purification was achieved by RP liquid chromatography on a Waters $\mathrm{C} 1810 \mu$ column in a water-acetonitrile $0-100 \%$ gradient in $0.05 \%$ TFA, detection at $214 \mathrm{~nm}$.

The purity was checked by FAB-MS (Fast Atom Bombardment Mass Spectrometry) on a JEOL double-focussing mass spectrometer with a FAB ion source, and a JMA DA6000 data system. An aliquot of the sample was dissolved in $30 \%$ acetic acid/water and evaporated on the FAB-target, then a mixture of $70 \%$ formic acid/water and glycerol (1:1) as a matrix was added, and the sample was bombarded with $10 \mathrm{keV}$ Xenon atoms. Spectra of positive ions were recorded in the range $m / z 50-2550$ with a resolution of 3000 .

Samples for NMR spectroscopy were prepared at 30-60 $\mathrm{mM}$ peptide concentration, $\mathrm{pH} 3.5(0.5)$ in either $99.9 \%$ ${ }^{2} \mathrm{H}_{2} \mathrm{O}$ or $90 \% \mathrm{H}_{2} \mathrm{O}-10 \%{ }^{2} \mathrm{H}_{2} \mathrm{O}$. (For ${ }^{2} \mathrm{H}_{2} \mathrm{O}$ solutions, the ' $\mathrm{pH}$ ' refers to the $\mathrm{pH}$-meter reading without correction for isotope effect.) The NMR measurements were recorded on a JEOL GSX 270 spectrometer. Assignments were made using two-dimensional COSY, ${ }^{15}$ two-dimensional double quantum filter COSY, ${ }^{16} \mathrm{C}-\mathrm{H}$ correlated spectroscopy, ${ }^{17}$ $J$-resolved and phase-sensitive $\operatorname{COSY}^{18,19}$ at $37^{\circ} \mathrm{C}$. Chemical shifts are given in parts per million $(\mathrm{ppm})$ relative to 3-trimethylsilylpropionic acid (TSP $\left.\delta_{\mathrm{H}}=0.00\right)$ for ${ }^{1} \mathrm{H}$ spec- tra and dioxane $\left(\delta_{C}=67.4\right)$ for ${ }^{13} \mathrm{C}$. Prior to the NMR measurements in ${ }^{2} \mathrm{H}_{2} \mathrm{O}$ the samples were lyophilized three times in ${ }^{2} \mathrm{H}_{2} \mathrm{O}$.

Cell binding. Polystyrene 96-well microtiter plates (NUNC immunolon) were coated overnight at room temperature with $50 \mu \mathrm{l}$ of bovine BSP (bone sialoprotein) $\left(5 \mu \mathrm{g} \mathrm{ml}^{-1}\right.$ in $0.15 \mathrm{M} \mathrm{NaCl}, 5 \mathrm{mM}$ sodium phosphate, $\mathrm{pH}$ 7.4). Samples $(50 \mu \mathrm{l})$ of the peptides to be tested for the capacity to inhibit cell binding to fibronectin were added to the microtiter plate in triplicate for various dilutions. Rat R1 cells were released from monolayer cultures on tissue culture plates by trypsin digestion. Cells $(500000)$ were suspended in $2.5 \mathrm{ml}$ of Ham's F12 medium, containing $0.1 \mathrm{mg} \mathrm{ml}^{-1}$ of bovine serum albumin.

A $50 \mu \mathrm{l}$ sample of the cell suspension was added to each peptide-containing well in the microtiter plate. After incubation for $2 \mathrm{~h}$ in a $\mathrm{CO}_{2}$-incubator to allow cells to attach, non-bound cells were carefully removed by rinsing.

Bound cells were quantified by measuring their lysosomal enzyme content. Thus, $N$-acetylglucosaminidase was liberated from the cells by treatment with detergent, and enzyme activity was measured using $p$-nitrophenyl 2 -acetamido-2-deoxy- $\beta$-D-glucopyranoside as the substrate. Bound cells are expressed in terms of absorbance of released $p$-nitrophenol. ${ }^{2}$

\section{Results}

Synthesis and FAB-MS. The increase in weight of the resin during synthesis of GRGDS(P)L was $80 \%$ of that theoretically expected. After release from the resin and acid deprotection the yield was $39 \%$. During the final deprotection of the phenyl groups from the phosphate moiety, we noticed that it was necessary to prehydrogenate the catalyst, since the phosphate group was quantitatively lost if the peptide and catalyst were hydrogenated together.

Synthesis and purification of GRGDSL and GRGDS(P)L, was monitored by FAB-MS $(\mathrm{m} / z 603$ and 683 , respectively). In FAB-MS of GRGDS(P)L we could see an extra peak at $m / z 604$. This was shown to be a fragment peak by addition of sodium chloride to the sample resulting in one additional $\mathrm{m} / \mathrm{z} 705$ peak. The $\mathrm{m} / \mathrm{z} 604$ fragment is probably formed by loss of the phosphate group. In both peptides FAB-MS showed a minor peak at $M-115$, probably due to incomplete incorporation of aspartic acid. This deletion impurity was shown by NMR spectroscopy to be less than $5 \%$.

NMR spectroscopy. ${ }^{1} \mathrm{H}$ NMR chemical shifts and spin coupling constants are collected in Table 1 . The ${ }^{13} \mathrm{C}$ NMR chemical shifts are found in Table 2 and the ${ }^{31} \mathrm{P}$ signal was found at $0.51 \mathrm{ppm}$ for GRGDS(P)L in the expected region.

Cell binding assays. The R1 cells did not show sufficient binding to plastic surfaces coated with osteopontin. There- 
PETTERSSON ET AL.

Table 1. ${ }^{1} \mathrm{H}$ NMR shifts of the hexapeptides GRGDSL ${ }^{a, b}$ and GRGDS(P)L., ${ }^{a, c}$

\begin{tabular}{lllll}
\hline $\begin{array}{l}\text { Amino } \\
\text { acid }\end{array}$ & $\mathrm{NH}$ & $\alpha-\mathrm{H}$ & $\beta-\mathrm{H}$ & $\gamma-\mathrm{H}$ \\
\hline
\end{tabular}

(a) GRGDSL ${ }^{a}$

\section{Gly}

\section{Arg}

Gly

Asp

Ser

Leu

(b)

Gly

Arg

Gly

Asp

$\operatorname{Ser}(\mathrm{P})$

Leu

$\begin{array}{ll}- & 3.88 \\ 8.68(6.2) & 4.34(7) \\ 8.61(6.0) & 3.94 \\ 8.15(7.3) & 4.72(6,7) \\ & \\ 8.21(7.3) & 4.47(5.5) \\ 7.99(7.8) & 4.28(8.3)\end{array}$

3.88

$4.34(7)$

$\alpha 14.04$

$\alpha 23.95$

( $\alpha \alpha$ 17)

8.22 (7.3)

$8.43(7.7)$

7.98 (7.4)
$4.74(7.0,6.5)$

4.57 (8.9)

$4.30(6)$
$1.83(-)$

$-$

$\beta 12.84$

$\beta 22.77$

( $\beta \beta$ 16.5)

3.87

$1.63(-)$

$1.88(-)$

$\beta 12.83$

B2 2.78

4.16

$1.66(-)$
$1.61(-)$

$1.66(-)$

$3.22(6.5)$

$-$

$1.67(-)$

$3.22(6,7)$

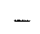

-

$\delta 10.91$ (5.9) $\delta 20.87$ (5.9)

$-$

$\delta 10.92$ (5.5) $\delta 20.87$ (5.9)

${ }^{a}$ The values in parentheses are spin-spin coupling constants in $\mathrm{Hz}$. ${ }^{0}$ The chemical shifts for the guanidine protons are $\varepsilon-\mathrm{NH} 7.22$ and $\eta-\mathrm{NH} 6.65$. $(-)=$ not detectable. ${ }^{c}$ The chemical shifts for the guanidine protons are $\varepsilon-\mathrm{NH} 7.20$ and $\eta-\mathrm{NH} 6.64$.

Table 2. ${ }^{13} \mathrm{C}$ NMR shifts for GRGDSL and GRGDS(P)L.

\begin{tabular}{lllll}
\hline Amino acid & $\alpha-\mathrm{C}$ & $\beta-\mathrm{C}$ & $\gamma-\mathrm{C}$ & $\delta-\mathrm{C}$ \\
\hline
\end{tabular}

(a) GRGDSL

$\begin{array}{lllll}\text { Gly } & 41.25 & - & - & - \\ \text { Arg } & 54.77 & 28.81 & 25.12 & 41.38 \\ \text { Gly } & 43.43 & - & - & - \\ \text { Asp } & 51.62 & 37.82 & - & - \\ \text { Ser } & 56.35 & 61.93 & - & - \\ \text { Leu } & 53.82 & 40.90 & 25.35 & \delta 123.16 \\ & & & & \delta 221.61\end{array}$

(b) GRGDS(P)L

$\begin{array}{lllll}\text { Gly } & 41.26 & - & - & - \\ \text { Arg } & 54.71 & 28.82 & 25.07 & 41.34 \\ \text { Gly } & 43.44 & - & - & - \\ \text { Asp } & 51.56 & 37.45 & - & - \\ \text { Ser(P) } & 55.22 & 64.81 & - & - \\ \text { Leu } & 53.93 & 40.80 & 25.28 & \delta 123.15 \\ & & & & \delta 221.59\end{array}$

fore cells were allowed to bind to BSP, which binds to the same vitronectin receptor. ${ }^{2}$ Binding was reproducible as indicated by the values for non-inhibited binding in Fig. 1. Peptides corresponding to the sequence around the BSP-cell binding region (PRGDTY) ${ }^{2}$ were effective in competing for binding to the BSP-coated surface and inhibited binding by some $90 \%$. Interestingly, the peptide corresponding to the binding sequence of osteopontin (GRGDSL) ${ }^{2}$ was equally efficient in inhibiting binding to BSP-coated surfaces (Fig. 1).

The phosphorylated peptide was much less efficient at inhibiting cell binding. The concentrations required were some 5-10 times higher for the phosphorylated peptide (Fig. 1). 


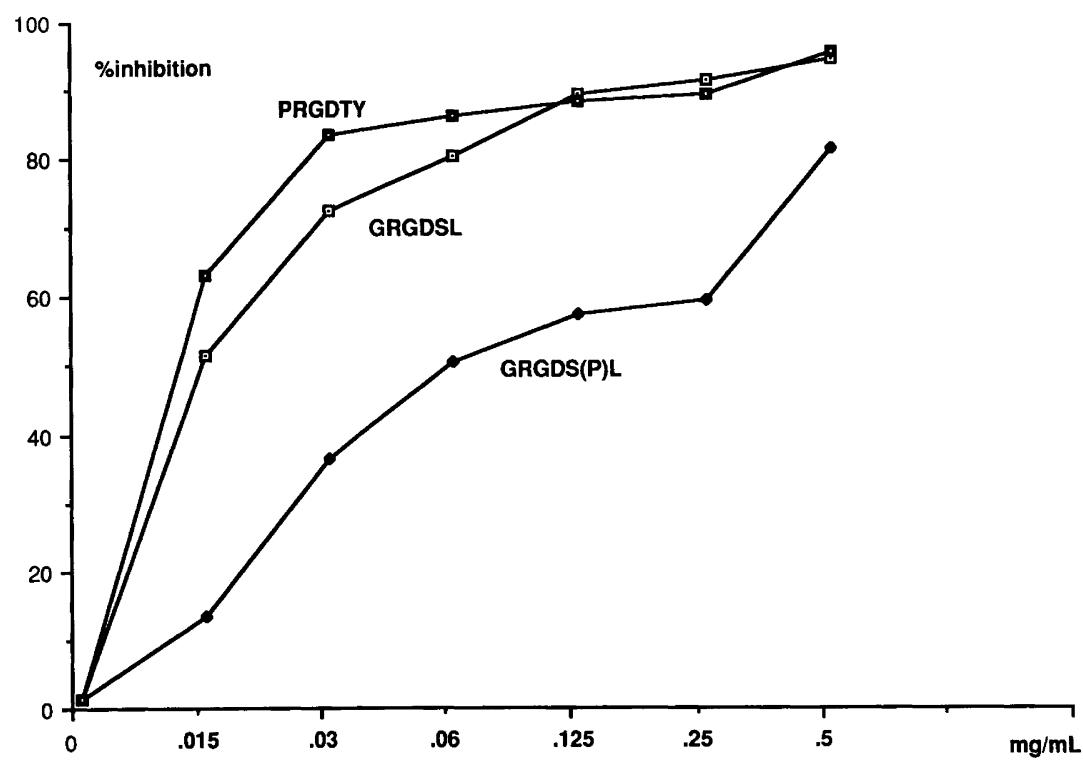

Fig. 1. Inhibition of cell attachment to fibronectin by the peptides PRGDTY, GRGDSL and GRGDS(P)L. Inhibition is given as percentage of binding relative to the total binding in the absence of peptide.

\section{Discussion}

Cells bound much more efficiently to surfaces coated with BSP than to those coated with osteopontin. This may result from the different location of the cell binding sequence in the proteins. In BSP it is located close to the $C$-terminus, while in osteopontin it is located in the middle part of the molecule. It is thus possible that this structure is exposed differently in the proteins, particularly when the proteins are bound to plastic surfaces.

It has previously been shown that cells bind to surfaces coated with BSP or osteopontin via their vitronectin receptor. Cells then, bind to the proteins via the same receptor. For technical reasons we therefore chose to study cell binding to surfaces coated with BSP.

In initial experiments we were able to verify that peptides corresponding to the sequences of the cell binding domain of BSP and osteopontin, respectively, were equally efficient at inhibiting binding to surfaces coated with BSP.

The phosphorylated peptide was much less efficient at preventing cell binding to BSP. On the other hand, the peptide at higher concentration did inhibit binding to BSP. It is somewhat surprising that a charged bulky group such as the phosphate at such a close location to the cell binding RGD-sequence proper, has such relatively minor effects on the cell binding properties.

Cell binding might therefore be dependent upon a conformation in which the phosphate group exerts little influence, or where the phosphate group is detached during the experiment.

The cells used in the present set of experiments represent a fibroblast not related to bone cells. Apparently this cell, like many other cells in culture, express the vitronectin receptor and can bind to the proteins studied. In initial experiments, attempts were made to use the osteoblastic
ROS 17/2.8 cells in studies of the cell binding. The cells did bind efficiently to the surface coated with BSP. This binding was efficiently inhibited by added peptides corresponding to both cell binding sequences. Interestingly, with these cells the efficiency with which the phosphorylated peptide inhibited cell binding was equal to that of the control peptide (data not shown). We interprete this as a dependence on the release of the phosphate groups caused by the activity of alkaline phosphatase released by the osteoblastic cells.

The abundance of biological phosphorylations, and their role in the flow of biochemical information in the living organism, makes imperative the study and elucidation of the influence of phosphate groups attached to peptides and proteins, by means of synthetic peptides. So far, no general method has been devised for the reliable production of a given phosphopeptide. The use of phenyl groups for the protection of the phosphate group on serine during synthesis is preferred since benzyl esters have been shown to be too acid-labile during synthesis according to the Boc protocol. ${ }^{8}$ However, the hydrogenolytic removal of the diphenyl phosphate protective group, that we used in the synthesis described in this paper, is not compatible with the presence of tyrosine in the peptide, since an attempt to synthesize PRGDT(P)Y by the same protocol yielded a well defined phosphorylated peptide containing cyclohexylalanine (data not shown). Details, such as the prehydrogenation of Adams' catalyst for removal of the phenyl ester groups from the phosphate moiety, are important as a means of keeping the phosphate group attached to the peptide.

Previously, in synthesis of phosphorylated peptides, arginine has been protected with the nitro group, which has to be removed by either HF or catalytic hydrogenolysis. 
Cleavage of the nitro group from arginine is known to be accompanied by side reactions such as the formation of ornithine. ${ }^{20}$ The most common protecting group used is tosylate, but this group is also removed by $100 \% \mathrm{HF}$. Some authors have claimed that HF cleavage can be used, ${ }^{21}$ but others, including ourselves, find that the phosphate group is quantitatively removed. ${ }^{22-24}$ Therefore, it is desirable to find alternative routes. The use of mesitylenesulfonyl (Mts) as a side-chain protecting group for arginine permitted the use of trifluoromethanesulfonic acid as cleaving agent instead of HF. The Mts protecting group is sufficiently stable under the conditions of Boc-synthesis.

Strong nucleophiles ${ }^{23,25}$ and organic bases ${ }^{26}$ should also be avoided, since these tend to cleave phosphate esters non-specifically. Phosphopeptides are also more sensitive than most unconjugated peptides ${ }^{27}$ and loss of the phosphate group is a problem when studying them by NMR spectroscopy in acidic aqueous solution.

The chemical shifts for the protons in GRGDS(P)L, show a high degree of similarity to those of GRGDSL. Only for the serine residue is a downfield shift of about $0.1-0.3 \mathrm{ppm}$ observed, an effect that is ascribed to the phosphate group. It is noteworthy that the $\beta$-protons of serine and arginine, in GRGDSL as well as in GRGDS(P)L, are magnetically equivalent, in contrast with the $\beta$-protons of serine in GRGDSP ${ }^{28}$ which show clearly separated shifts for the two protons. The serine NH-proton suffers a downfield shift of about $0.2 \mathrm{ppm}$, presumably due to the phosphate group. The ${ }^{13} \mathrm{C}$ chemical shifts show great similarity between the two peptides, except for the more downfield shift of the serine $\beta$-carbon in the phosphorylated peptide. Furthermore, signals of carbon atoms $\alpha$ to the free carboxy groups of aspartic acid and leucine are of low amplitude due to broadening in the spectra of both peptides.

The information thus indicates that there is a greater difference in conformation between the fully adhesive peptides GRGDSP and GRGDSL derived from fibronectin and osteopontin, respectively, than between GRGDSL and GRGDS(P)L, although the phosphorylated peptide shows a considerably lower ability to inhibit cell adhesion.

Acknowledgements. This work was supported by grants from the Swedish National Board for Technical Development.

\section{References}

1. Heinegård, D. and Oldberg, Å. FASEB J. 3 (1989) 2042.

2. Oldberg, Å., Franzen, A., Heinegård, D., Pierschbacher, M. and Ruoslahti, E. J. Biol. Chem. 263 (1988) 19433.

3. Reinholt, F. P., Hultenby, K., Oldberg, §. and Heinegård, D. Proc. Natl. Acad. Sci., USA 87 (1990) 4473.

4. Fölsch, G. Sven. Kem. Tidskr. 79 (1967) 38.

5. Ferrel, R. E., Olcott, H. S. and Fraenkel-Conrat, H. J. J. Am. Chem. Soc. 70 (1948) 2101.

6. Kemp, B. E., Graves, D. J., Benjamin, E. and Krebs, E. G. J. Biol. Chem. 252 (1977) 4888.

7. Blumenthal, D. K. Peptides and Protein Phosphorylation, CRC Press Cleveland, 1988.

8. Perich, J. W., Alewood, P. F. and Johns, R. B. Tetrahedron Lett. 27 (1986) 1373.

9. Perich, J. W., Valerio, R. M. and Johns, R. B. Tetrahedron Lett. 27 (1986) 1377.

10. Barany, G. and Merrifield, R. B. In: Gross, E. and Meienhofer, J., Eds., The Peptides, Academic Press, 1979, Vol. 2, Chap. 1.

11. Clark, J. H. and Miller, J. M. Tetrahedron Lett. 7 (1977) 599.

12. Sarin, V. K., Kent, S. B. H., Tam, J. P. and Merrifield, R. B. Anal. Biochem. 117 (1981) 147.

13. Tam, J. P., Heath, W. F. and Merrifield, R. B. J. Am. Chem. Soc. 105 (1983) 6442.

14. Perich, J. W., Alewood, P. F. and Johns, R. B. Synthesis (1986) 572.

15. Aue, W. P., Bartholdi, E. and Ernst, R. R. J. Chem. Phys. 64 (1976) 2229.

16. Paintini, U., Sørensen, O. and Ernst, R. R. J. Am. Chem. Soc. 104 (1982) 6800.

17. Bodenhausen, G. and Freeman, R. J. Magn. Reson. 28 (1977) 471

18. States, D. J., Haberkorn, R. A. and Ruben, D. J. J. Magn. Reson. 48 (1982) 286.

19. Marion, D. and Wüthrich, K. Biochem. Biophys. Res. Commun 113 (1983) 967.

20. Yamashiro, D., Blake, J. and Li, C. H. J. Am. Chem. Soc. 94 (1972) 2855.

21. Gibson, B. W., Falich, A. M., Burlingame, A. L., Nadasdi, L., Cac Nguyen, A. and Kenyon, G. L. J. Am. Chem. Soc. 109 (1987) 5343.

22. Arendt, A., Palczewski, K., Moore, W. T., Caprioli, R. M., McDowell, J. H. and Hargrave, P. A. Int. J. Pept. Protein Res. 33 (1989) 4687.

23. Kitas, E. A., Perich, J. W., Johns, R. B. and Tregear, G. W. Tetrahedron Lett. 29 (1988) 3591.

24. Otvos, L., Elekes, I. and Lee, V. M.-Y. Int. J. Pept. Protein Res. 34 (1989) 129.

25. Kitas, E. A., Perich, J. W., Tregear, G. W. and Johns, R. B. J. Org. Chem. 55 (1990) 4181.

26. Pacquet, A. Tetrahedron Lett. 31 (1990) 5269.

27. Bunton, C. A., Llewellyn, D. R., Oldham, K. G. and Vernon, C. A. J. Chem. Soc. (1958) 3574.

28. Mickos, H., Bahr, J. and Lüning, B. Acta Chem. Scand. 44 (1990) 161

Received October 17, 1990. 